\title{
Dinamika Psikologis Pelaku Kejahatan Pembunuhan Berencana di Lapas Klas 1 Surabaya Porong
}

\author{
Inez Lowis \\ Fakultas Psikologi, Universitas Surabaya \\ nz_lowis@yahoo.com
}

\begin{abstract}
Murder, whether planned or not, is not a serious crime. The high number of murder cases that continues to increase is of particular concern to every country, including Indonesia. Many factors influence individuals to commit crimes such as murder. This research was conducted to determine the psychological factors that influence the murder committed by murder convicts. The research was conducted using a qualitative design, using a case study phenomenology approach. The results and findings show that high aggression, impulsive tendencies, not having a good role model, and low emotional regulation skills are the main factors in the subject of committing murder. The intervention was carried out in the form of psychoeducation to the subject. The intervention was successful enough to find out about the factors that influence a crime and its causes and to help subjects understand how to regulate emotions properly.
\end{abstract}

Keywords: factor; murder; planning.

\begin{abstract}
Abstrak
Pembunuhan baik yang direncanakan maupun tidak, merupakan tidak kejahatan yang serius. Tingginya kasus pembunuhan yang terus meningkat menjadi perhatian khusus pada setiap negara, termasuk Indonesia. Terdapat banyak faktor yang mempengaruhi individu untuk melakukan tindak kriminal seperti pembunuhan. Penelitian ini dilakukan untuk mengetahui faktor-faktor psikologis yang berpengaruh terhadap tindak pembunuhan yang dilakukan oleh narapidana kasus pembunuhan. Penelitian dilakukan menggunakan desain kualitatif, menggunakan pendekatan fenomenologi studi kasus. Hasil dan temuan menunjukan bahwa tingginya faktor agresi, kecenderungan impulsif, tidak memiliki role model yang baik, dan rendahnya kemampuan regulasi emosi menjadi faktor utama subjek melakukan pembunuhan. Dilakukan intervensi berupa psikoedukasi kepada subjek. Intervensi cukup berhasil untuk mengetahui mengenai faktor yang mempengaruhi tindakan kriminal dan penyebabnya, serta membantu subjek memahami bagaimana meregulasi emosi dengan baik.
\end{abstract}

Kata kunci: faktor; pembunuhan; berencana. 


\section{Pendahuluan}

Pembunuhan merupakan salah satu bentuk tindak kriminal yang diatur dalam peraturan perundangan Indonesia. Pembunuhan dapat terjadi baik karena direncanakan maupun tidak direncanakan. Pembunuhan yang dilakukan secara terencana atau kemudian lebih dikenal sebagai pembunuhan berencana, dan sangsi bagi pelakunya sudah diatur dalam kitab undang-undang hukum pidana (KUHP) pasal 340 yang berbunyi "Barang siapa dengan sengaja dan dengan rencana terlebih dahulu merampas nyawa orang lain, diancam karena pembunuhan dengan rencana, dengan pidana mati atau pidana penjara seumur hidup atau selama waktu tertentu, paling lama dua puluh tahun". Dengan ancaman hukuman hingga seumur hidup bahkan hukuman mati, menunjukan bahwa pembunuhan berencana merupakan tindak kriminal yang sangat serius dan ditindak tegas oleh peraturan perundang-undangan yang ada.

Kasus kejahatan pembunuhan yang banyak terjadi dewasa ini kerap menjadi pemberitaan publik. Badan Pusat Statistik mencatat bahwa terjadi kenaikan signifikan pada kasus kejahatan pembunuhan di tahun 2015. Pada tahun 2014, kasus kejahatan pembunuhan yang berhasil dicatat oleh Badan Pusat Statistik adalah sebanyak 1.277 kasus. Kemudian pada tahun 2015, kasus kejahatan pembunuhan yang tercatat meningkat cukup banyak yaitu sebanyak 1.491 kasus.

Seseorang yang melakukan kejahatan pembunuhan digerakkan oleh beberapa faktor. Pada kasus kejahatan pembunuhan berencana, biasanya calon pembunuh sudah mengetahui siapa calon korban yang akan dibunuhnya. Faktor pemicu terjadinya kejahatan pembunuhan tersebut adalah konflik sosio-emosional yang disebabkan karena seseorang merasa kecewa, sakit hati, atau dendam pada orang lain. Dengan cara yang ekstrim, perasaan kecewa, sakit hati, atau dendam ini dilampiaskan dengan cara membunuh calon korban yang menyebabkan perasaan-perasaan tersebut muncul (Dariyo, 2013).

Perilaku kriminal seperti pembunuhan erat kaitannya dengan kecenderungan agresi pada individu. Dalam penelitian yang dilakukan oleh Buss, \& Perry (1992), menunjukan bahwa perilaku menyakiti orang lain secara fisik 
seperti yang terjadi pada kasus pembunuhan atau perkelahian, menunjukan adanya kecenderungan agresi yang tinggi. Perilaku agresi pada umumnya diikuti oleh rendahnya self-esteem pada diri individu (Bushman et al., 2009). Selain itu, tindak kriminal juga dapat dipengaruhi oleh berbagai aspek psikologi lain seperti narcissism, psychopathy, dan Machiavellianism yang juga berhubungan dengan agresi (Paulhus \& Williams, 2002). Berdasarkan PPDGJ III bahwa gangguan pada perilaku kriminal dapat digolonggkan dalam gangguan intermittent explosive, yang memiliki kriteria, gagal mengendalikan impuls agresif, seperti agresi verbal dan fisik, perilaku merusak, lonjakan agresif berulang tanpa terkendali, serta perilaku agresi yang memiliki konsekuensi pada diri sendiri dan orang lain.

Terdapat berbagai aspek psikologis yang dapat berpengaruh terhadap tindak kriminal seperti pembunuhan. Maka dari itu, sangat penting mengetahui dinamika psikologi dan faktor-faktor yang dapat mendorong individu melakukan tindakan kriminal sangatlah penting. Hal ini kemudian dapat menjadi bahan pertimbangan dalam menentukan rancangan intervensi bagi tersangka, maupun melakukan langkah preventif guna menurunkan angka tindak kriminal yang cenderung meningkat dari tahun ke tahun. Oleh sebab itu dalam penelitian ini, peneliti melakukan studi kasus terhadap narapidana Lapas Porong seorang lakilaki berusia 32 tahun dimana ia dihukum atas tuduhan pembunuhan berencana.

Penelitian ini kemudian akan dikaji berdasarkan beberapa perspektif diantarnya adalah modeling \& moral disengagement (Albert Bandura), kontrol terhadap perilaku manusia, teori kepribadian Adler, dan kriminalitas. Modeling melibatkan penambahan dan atau pengurangan tingkah laku yang teramati, menggeneralisir berbagai pengamatan dan melibatkan proses kognitif. Modelling dilakukan melalui empat proses yaitu perhatian, representasi, peniruan tingkah laku, dan motivasi dan penguatan. Individu juga dapat mengatur tindakantindakan diri sendiri melalui standar-standar moral mengenai sikap tertentu. Dengan menjustifikasi moralitas tindakannya sendiri, individu dapat memisahkan atau melepaskan diri dari konsekuensi perilakunya. Perilaku individu dikontrol oleh desakan lingkungan. Desakan ini bisa terwujud oleh masyarakat, individu tertentu, atau diri sendiri.

Jurnal Insight Fakultas Psikologi Universitas Muhammadiyah Jember | 365 
Teori inti yang dikembangkan Adler adalah bahwa manusia dilahirkan dengan tubuh yang lemah dan inferior, sebuah kondisi yang mengarah pada perasaan-perasaan inferioritas dan ketergantungan pada orang lain. Oleh karena itu, kepedulian sosial sangat inheren dalam manusia dan menjadi standar tertinggi kesehatan psikologis. Kriminalitas adalah tindakan yang merugikan baik secara ekonomis maupun psikologis, dan melanggar hukum serta norma-norma sosial (Kartono, 1999). Hurwitz (1986) menambahkan bahwa terdapat faktor-faktor yang menyebabkan seseorang melakukan tindakan kriminalitas ialah faktor Internal dan faktor eksternal. Faktor internal terdiri atas umur, faktor pembawaan kriminal faktor biologik secara genothype dan phenotype. Faktor Eksternal terdiri atas ,Faktor lingkungan, Kemiskinan, Pendidikan, Bacaan dan film.

Menurut Hare, terdapat beberapa ciri kriminalitas, yaitu Glibness/Superficial Charm, selalu menyampaikan sesuatu yang sangat meyakinkan, terlihat pintar, dan dapat membuat orang terkesan akan dirinya. Grandiose Sense of Self Worth, memandang diri sangat tinggi. Need for Stimulation/proneness to Boredom, kebutuhan untuk selalu terstimulasi hal-hal menarik. Pathological Lying, kecenderungan untuk berbohong, bahkan tidak merasa malu ketika dikonfrontasi dan cenderung mengubah cerita dan fakta. Selalu memiliki penjelasan dan berdalih. Conning/Mannipulative, penggunaan tipuan dan penipuan untuk memanipulasi orang lain. Lack of Remorse or Guilt, tetap tenang dan tidak memiliki rasa bersalah dalam menghadapi konsekuensi negatif dari perilakunya. Shallow Affect, kesulitan dalam merasakan emosinya, sehingga cenderung dingin. Callous/Lack of Empathy, lebih fokus pada diri sendiri dan melakukan segala sesuatu sesuka hati tanpa merasa menyesal. Parasitic Lifestyle, bergantung pada orang lain secara finansial. Poor Behavioral Controls, Emosi menjadi mudah meledak ketika adanya frustrasi, kegagalan, disiplin, dan kritikan mengenai dirinya. Promiscuous Sexual Behavior, memiliki hubungan seksual tanpa memiliki perasaan pada pasangan tersebut. Early Behavioral Problem, memiliki permasalahan perilaku pada masa kecil. Lack of Realistic, Long term Goal, tidak memiliki tujuan masa depan. Impulsive, kesulitan dalam pengelolaan diri karena cenderung ingin memenuhi kebutuhan diri sendiri. 
Irresponsibility, tidak bertanggung jawab dan berkomitmen dengan orang lain. Failure to Accept Responsibility for Own Action, individu yang tidak dapat menerima tanggung jawab diri sendiri. Many short-term Marital Relationship, individu yang sering melupakan satu-satu. Juvenille Delinquency, yang kekerasan yang dilakukan ketika akan melakukan seks. Revocation of Conditional Release, memiliki pengalaman traumatis seperti kekerasan namun kini telah bebas. Criminal Versality, pengalaman individu terhadap perbedaan di rumah atau di luar.

\section{Metode}

Penelitian ini merupakan penelitian studi kasus berkaitan dengan perilaku kriminal pembunuhan yang dilakukan pada "Lapas Klas I Surabaya (Lapas Porong)". Dengan tujuan untuk mendapatkan pengetahuan mengenai suatu fenomena yang terjadi, penelitian ini pun dirancang menggunakan metode penelitian kualitatif dengan pendekatan studi kasus. Studi kasus dilakukan guna mengungkap data pada fenomena yang tidak memiliki konteks yang tegas dan menggunakan berbagai sumber bukti sebagai acuan (Yin, 1997).

\section{Partisipan}

Subjek peneltian adalah seorang narapidana kasus kejahatan pembunuhan berencana yang baru pertama kali terjerat hukum. Subjek ditahan di Lembaga Pemasyarakatan (Lapas) Klas 1 Surabaya-Porong dengan pasal 340 KUHP dalam pembunuhan berencana. Subjek dikenakan hukuman selama 18 tahun dan telah menjalani hukumannya selama kurang lebih 4 tahun.

\section{Metode Pengumpulan Data}

Dalam penelitian ini, digunakan sejumlah metode asesmen oleh peneliti guna memahami dinamika psikologis pelaku kejahatan pembunuhan berencana ini. Berbagai macam tes psikologi yang diberikan pada subjek penelitian seperti WB, Grafis, Rorschach, TAT, Hare, juga melalui metode wawancara dan observasi. 
a. Wawancara

Wawancara pada dasarnya merupakan teknik yang biasa digunakan untuk menggali informasi. Sugiyono (2008) berpendapat bahwa wawancara merupakan teknik komunikasi yang digunakan untuk menggali informasi secara mendalam. Pada umumnya wawancara dilakukan melalui pertemuan secara langsung, dengan harapan dapat mendapatkan informasi secara faktual dengan secara bersamaan melakukan penilaian terhadap respons individu. Dalam penelitian ini wawancara dilakukan secara terstruktur dengan daftar pertanyaan yang sudah disiapkan sebelumnya.

b. Observasi

Observasi pada umumnya tersusun atas kegiatan pengamatan yang dilakukan secara langsung terhadap subjek observasi, dengan tujuan memperoleh gambaran mengenai subjek guna memperoleh baik satu maupun sekumpulan data. Arikunto (2002) mendefinisikan observasi sebagai kegiatan pengamatan yang melibatkan pemusatan perhatian terhadap subjek observasi menggunakan seluruh teknik indra.

c. Asesmen

Asesmen dalam penelitian ini adalah serangkaian pengukuran yang dilakukan dengan berbagai instrumen. Hal ini sejalan dengan pendapat Barbera (dalam Ali, Tawil, Nurhayati, \& Yunus, 2018) yang menyatakan bahwa asesmen merupakan serangkaian proses yang disusun secara sistematis untuk mendapatkan sejumlah informasi.dalam penelitian ini, asesmen dilakukan menggunakan berbagai instrumen, seperti WB, tes Grafis (Baum \& DAP), TAT, dan Hare.

Tabel 1. Asesmen

\begin{tabular}{|c|c|c|c|c|c|c|}
\hline \multirow{2}{*}{ Gejala/Aspek } & \multicolumn{6}{|c|}{ Teknik penggalian data } \\
\hline & 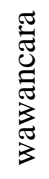 & $\begin{array}{l}\overline{\tilde{z}} \\
\stackrel{0}{0} \\
\overrightarrow{0} \\
0 \\
0\end{array}$ & $\sum_{3}^{\infty}$ & 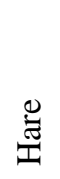 & 选 & 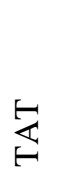 \\
\hline \multicolumn{7}{|l|}{ Fungsi kepribadian } \\
\hline Kemampuan intelektual dan kognitif & $\sqrt{ }$ & $\sqrt{ }$ & $\sqrt{ }$ & & $\sqrt{ }$ & $\sqrt{ }$ \\
\hline Ambisi & $\sqrt{ }$ & & $\sqrt{ }$ & & $\sqrt{ }$ & \\
\hline Kontrol dan dorongan & $\sqrt{ }$ & & $\sqrt{ }$ & $\sqrt{ }$ & $\sqrt{ }$ & $\sqrt{ }$ \\
\hline Kehidupan afeksi dan emosi & $\sqrt{ }$ & $\sqrt{ }$ & & $\sqrt{ }$ & $\sqrt{ }$ & $\sqrt{ }$ \\
\hline
\end{tabular}




\begin{tabular}{|c|c|c|c|c|c|c|}
\hline \multirow{2}{*}{ Gejala/Aspek } & \multicolumn{6}{|c|}{ Teknik penggalian data } \\
\hline & 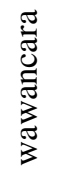 & $\begin{array}{l}\bar{a} \\
\overline{0} \\
\overrightarrow{0} \\
0 \\
00 \\
0\end{array}$ & $\sum_{3}^{\infty}$ & 䒕 & 遏 & 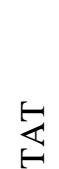 \\
\hline Relasi sosial dan penyesuaian diri & $\sqrt{ }$ & $\sqrt{ }$ & $\sqrt{ }$ & $\sqrt{ }$ & $\sqrt{ }$ & $\sqrt{ }$ \\
\hline Konflik dan cara penyelesaian masalah & $\sqrt{ }$ & & $\sqrt{ }$ & & $\sqrt{ }$ & $\sqrt{ }$ \\
\hline Insecurity dan anxiety & $\sqrt{ }$ & $\sqrt{ }$ & & & $\sqrt{ }$ & $\sqrt{ }$ \\
\hline
\end{tabular}

\section{Hasil dan Pembahasan}

Berdasarkan hasil pemeriksaan, dapat diketahui bahwa subjek yang bersangkutan merupakan individu yang memiliki kecenderungan agresi yang tinggi, memiliki kemampuan intelektual dan kognitif yang memadai, mengalami permasalahan dalam aspek kontrol dan dorongan, memiliki kebutuhan yang tinggi atas afeksi, cenderung menjadikan konflik sebagai cara penyelesaian masalah, serta memiliki insecurity dan anxiety yang cukup tinggi. Kecenderungan agresi yang tinggi muncul pada sejumlah hasil tes yang dilakukan pada subjek, seperti pada hasil tes grafis, TAT, hasil wawancara, observasi dan tes MMPI. Kecenderungan tindak kriminal kemudian didorong oleh permasalahan pribadi yang dialami. Kegagalan mengontrol emosi, disertai dengan tingginya kecenderungan agresi pada pada diri subjek, pada akhirnya disalurkan dalam bentuk menyakiti orang lain. Dalam kasus ini, pembunuhan terjadi dikarenakan subjek tidak dapat mengatasi lonjakan agresi yang terjadi secara impulsif. Perasaan tidak aman dalam berelasi yang disertai kebutuhan yang tinggi akan afeksi, menjadikan subjek sebagai individu yang sangat sensitif terhadap relasinya. Peneliti menyimpulkan bahwa subjek mengalami gangguan Intermittent Explosive sehingga ia kesulitan dalam mengelola emosinya.

Diketahui bahwa subjek juga memiliki kecenderungan manipulatif. Mudah baginya untuk menciptakan cerita baru untuk memenuhi kebutuhannya. Meskipun memiliki kemampuan untuk berpikir dengan cukup rasional ketika dihadapkan oleh masalah, subjek kurang mampu menyelesaikan permasalahan yang bersifat emosional. Ia cenderung tidak tahan terhadap tekanan dan impulsif. 
Berdasarkan asesmen yang telah dilakukan, dapat disimpulkan bahwa perilaku kriminal yang dilakukan oleh subjek merupakan akibat dari sulitnya subjek dalam mengelola emosinya dan cenderung tidak dapat menyelesaikan masalah yang mengandung unsur emosional. Kasus perselingkuhan menjadi sumber permasalahan yang besar bagi subjek karena ia memiliki kecemasan dalam afeksi dan harga diri terhadap isu seksualitas atau kejantanan. Menghadapi hal tersebut, subjek yang tidak memiliki cara untuk coping stress, membuat subjek bertindak secara impulsif berdasarkan emosi, dan dengan kemampuan intelektual yang tinggi, subjek dapat menghalalkan segala cara agar keinginannya dapat terlaksana.

\section{Kesimpulan dan Saran}

\section{Kesimpulan}

Intervensi jangka pendek diberikan dalam rupa psikoedukasi, dalam mengenal diri sendiri dan dan regulasi emosi, untuk membantu mengevaluasi dampak positif dan negatif atas penanaman moral yang ada, serta faktor penyebab dirinya melakukan tindakan kriminal. Hal ini bertujuan untuk membantu subjek menyadari proses emosi yang terjadi dalam dirinya, mengevaluasi dan mengelola emosi yang dirasakan, serta mampu memberikan respons yang lebih adaptif.

Melalui keseluruhan rangkaian proses intervensi yang diberikan, dapat disimpulkan bahwa refleksi yang diberikan pada subjek dapat membantunya untuk lebih memahami penyebab ia melakukan pembunuhan, serta stimulus dan reaksi emosi dalam dirinya. Psikoedukasi juga dapat membantu subjek untuk memahami proses marah yang terjadi pada dirinya dan cara-cara lain yang bisa dilakukan selain melakukan konfrontasi, juga lebih memahami mengenai konsep regulasi emosi dan cara lain yang dapat ia lakukan untuk menyalurkan emosinya. Proses regulasi emosi merupakan proses jangka panjang sehingga belum terlihat efektivitasnya. 


\section{Saran}

Subjek diharapkan mampu mencari sosok atau figur yang dapat memberikan arahan dengan lebih tepat mengenai norma. Subjek lebih dekat dengan Tuhan sehingga dapat menanamkan norma yang telah dipelajarinya dari agama. Subjek diharapkan dapat mengaplikasikan teknik yang sudah diajarkan ketika menghadapi stimulus emosional. Subjek diharapkan dapat mengubah konsep berpikirnya tentang norma tanpa mementingkan diri sendiri Bagi Lapas Kelas IB Surabaya, diharapkan dapat memberikan bantuan berupa konseling dan pengarahan dalam mengembangkan diri, terutama dalam hal terkait emosi.

\section{DAFTAR PUSTAKA}

Ali, M. H., Tawil, M., Nurhayati, N., \& Yunus, S. R. (2018). Pengembangan Asesmen Proyek dalam Pembelajaran Fisika. Sainsmat, 7(1), 34-41.

Arikunto, S. 2002. Prosedur Penelitian : Suatu Pendekatan Praktek. Rineka Cipta. Jakarta.

Bandura, A. (1999). Moral disengagement in the perpetration of inhumanities. Personality and Social Psychology Review. 3 (3): 193-209

Bushman, B. J., Baumeister, R. F., Thomaes, S., Ryu, E., Begeer, S., \& West, S. G. (2009). Looking again, and harder, for a link between low self-esteem and aggression. Journal of Personality, 77(2) (pp. 427-446).

Buss, A. H., \& Perry, M. . 1992. The aggression questionnaire. Journal of Personality and Social Psychology, 63 (pp. 452-459).

Gerungan, W. A. (2004). Psikologi sosial. Bandung: Refika Aditama

Feist, J., \& Feist, G. J. (2008). Theories of personality. Yogyakarta: Pustaka Pelajar

Paulhus, D. L, \& Williams, K. M. (2002). The dark triad of personality: Narcissism, Machiavellianism, and psychopathy. Journal of Research in Personality, 36(6) (pp. 556-563).

Ramadhan, A., \& Hafsaridewi, R. (2017). Dampak Perubahan Lingkungan Terhadap Perkembangan Aktivitas Ekonomi dan Kesejahteraan Masyarakat Pesisir di Kawasan Segara Anakan. Jurnal Sosial Ekonomi Kelautan dan Perikanan, 7(1), 33-53. 
Sugiyono. 2008. Metode Penelitian Kuantitatif Kualitatif dan R\&D (edisi pertama). Alfabeta. Bandung.

Yin, Robert K. 1997. Studi Kasus (Desain dan Metode). Jakarta : PT.Raja Grafindo Persada. 